\title{
Neuroanatomy of pediatric postoperative cerebellar cognitive affective syndrome and mutism
}

Neurology ${ }^{\circledR}$ 2020;94:414. doi:10.1212/WNL.0000000000008668

In the editorial "Neuroanatomy of pediatric postoperative cerebellar cognitive affective syndrome and mutism" by Schmahmann, ${ }^{1}$ first published online September 16, 2019, Dr. Albazron's last name was misspelled. It appears correctly in the October 15, 2019, issue. The author and the editorial team regret the error.

\section{Reference}

1. Schmahmann JD. Neuroanatomy of pediatric postoperative cerebellar cognitive affective syndrome and mutism. Neurology 2019;93: 693-694.

\section{A large multicenter study of pediatric myotonic dystrophy type 1 for evidence-based management}

Neurology ${ }^{\circledR}$ 2020;94:414. doi:10.1212/WNL.0000000000008819

In the article "A large multicenter study of pediatric myotonic dystrophy type 1 for evidencebased management" by Lagrue et al., the sentence in "Discussion" (p. e861) should have corresponded with the data in figure 1c and read: "In comparison to previous reports, the observed paternal transmission rate was higher than expected (12.7\% in the CF, $42 \%$ in the IF, and $68.4 \%$ in the JF)." The authors regret the error.

\section{Reference}

1. Lagrue E, Dogan C, De Antonio M, et al. A large multicenter study of pediatric myotonic dystrophy type 1 for evidence-based management. Neurology 2019;92:e852-e865.

\section{Self-management program improves participation in patients with neuromuscular disease}

A randomized controlled trial

Neurology ${ }^{\circledR}$ 2020;94:414. doi:10.1212/WNL.0000000000008713

In the article "Self-management program improves participation in patients with neuromuscular disease: A randomized controlled trial” by Veenhuizen et al., ${ }^{1}$ first published online September 30, 2019, the affiliations should have read: From the Departments of Rehabilitation (Y.V., E.H.C.C., N.B.M.V., D.M.M., J.T.G., A.C.H.G.) and Neurology (B.G.M.v.E.), Donders Institute for Brain, Cognition and Behaviour, Radboud University Medical Center, Nijmegen; Department of Health Evidence (M.A.J.), Radboud Institute for Health Sciences, Radboud University Medical Center, Nijmegen; and Rehabilitation Center Klimmendaal (N.B.M.V., B.J.v.K., A.H.), Arnhem, the Netherlands. The affiliations appear correctly in the October 29, 2019, issue. The publisher regrets the error.

\section{Reference}

1. Veenhuizen Y, Cup EHC, Jonker MA, et al. Self-management program improves participation in patients with neuromuscular disease: a randomized controlled trial. Neurology 2019;93:e1720-e1731. 


\title{
Neurology
}

\section{Neuroanatomy of pediatric postoperative cerebellar cognitive affective syndrome and mutism}

Neurology 2020;94;414 Published Online before print February 7, 2020

DOI 10.1212/WNL.0000000000008668

This information is current as of February 7, 2020

\author{
Updated Information \& \\ Services \\ including high resolution figures, can be found at: \\ http://n.neurology.org/content/94/9/414.1.full \\ References \\ This article cites 1 articles, 1 of which you can access for free at: \\ http://n.neurology.org/content/94/9/414.1.full\#ref-list-1 \\ Permissions \& Licensing \\ its entirety can be found online at: \\ http://www.neurology.org/about/about_the_journal\#permissions \\ Reprints \\ Information about ordering reprints can be found online: \\ http://n.neurology.org/subscribers/advertise
}

Information about reproducing this article in parts (figures,tables) or in

Neurology ${ }^{\circledR}$ is the official journal of the American Academy of Neurology. Published continuously since 1951, it is now a weekly with 48 issues per year. Copyright @ 2020 American Academy of Neurology. All rights reserved. Print ISSN: 0028-3878. Online ISSN: 1526-632X.

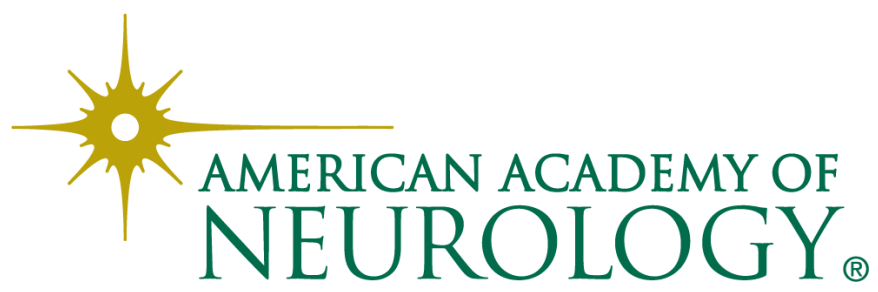

